\title{
Åben skole i Region Sjælland
}

\author{
Bettina Buch, docent, Professionshøjskolen Absalon, \\ Læreruddannelsen, bbu@pha.dk \\ Mari-Ann Skovlund Jensen, Professionshøjskolen Absalon, \\ Læreruddannelsen, msj@pha.dk \\ Dorrit Hansen, Professionshøjskolen Absalon, Læreruddannelsen, \\ doha@pha.dk \\ Birgit Brænder, Professionshøjskolen Absalon, Læreruddannelsen, \\ brb@pha.dk
}

\begin{abstract}
Resumé
I artiklen gennemgås en undersøgelse af brugen af åben skole i Region Sjællands kommuner. Data udgøres af hjemmesider fra 16 kommuner samt interviews med en kontaktperson fra 14 kommuner. Data er analyseret ud fra ministeriets bekendtgørelses fire kategorier af åben skole-samarbejde: kultur, natur, foreninger, erhvervsliv samt forhold som kommunale strategier og indsatser og graden af forpligtelse for lærerne. Studiet viser, at kommunerne i regionen er godt i gang med at implementere åben skole, men at der er store forskelle kommunerne imellem. Studiet viser, at især samarbejdet med kulturinstitutioner er stærkt, men også foreninger og erhvervsliv er godt repræsenteret. Til slut diskuteres forholdet mellem åben skole og skole uden for skolen, gensidigheden i samarbejdet og områder, der stadig kræver belysning gennem forskning.
\end{abstract}

Nøgleord: åben skole, skole-museum-samarbejde, skole-erhvervsliv-samarbejde, skole-naturinstitutioner-samarbejde, skole-forening-samarbejde

\begin{abstract}
In this article a study of Open School in Region Zealand is described. Data consists of homepages from 16 municipalities about Open School and interviews with one contact person from 14 municipalities. Data are analyzed using the four categories for cooperation in the Open School Ministerial Order: cultural institutions, societies for nature, associations, and the business community. Further we look upon the strategies and efforts made by each municipality and to which degree teachers are obliged to carry out Open School. Although differences are found, the study shows that most municipalities in the region have implemented Open School to some degree. The study shows that the cooperation with cultural institutions such as museums is the most wide spread followed by cooperation with associations such as sports associations and the local business communities. Finally, Open School as concept is discussed along with areas that need more research.
\end{abstract}

Keywords: Open School, cooperation between museums and school, cooperation between business and school, cooperation between nature associations and school, cooperation between associations and school, school-partnerships 


\section{Indledning}

Med folkeskolereformen fra 2014 fik Danmark en række nye tiltag omkring undervisningen i grundskolen. Et af dem er, at skolen i højere grad skal samarbejde med det omkringliggende samfund. Bekendtgørelsen fremhæver, at der kan samarbejdes med foreninger, erhvervslivet, kulturinstitutioner og andre interessenter uden for skolen (Bekendtgørelse af lov om folkeskolen, 2017):

\section{$\S 3$, stk. 4. Skolerne indgår i samarbejder, herunder i form af partner- skaber, med virksomheder, institutioner for erhvervsrettet uddannelse, lokalsamfundets kultur-, folkeoplysnings-, idræts- og foreningsliv og kunst- og kulturskoler, med lokale fritids- og klubtilbud og med de kom- munale eller kommunalt støttede musikskoler og ungdomsskoler, der kan bidrage til opfyldelsen af folkeskolens formål og mål for folkeskolens fag og obligatoriske emner. Kommunalbestyrelsen fastlægger mål og rammer for skolernes samarbejder, og skolebestyrelsen fastsætter prin- cipper for samarbejdet.}

I 2017 blev det indskærpet, at der også skulle fokuseres på samarbejdet med erhvervslivet (Danmarks Evalueringsinstitut, 2018b).

Siden har en række undersøgelser vist, at netop arbejdet med at åbne skolen mod omverdenen var et af de tiltag fra reformen, skolerne kom senest i gang med at implementere, fx oplevede eleverne ikke nogle ændringer i forhold til baselinemålingerne i årene umiddelbart efter reformen (Nielsen et al., 2015).

Skolens åbning mod verden udenfor som en måde at gøre skolens undervisning mere vedkommende og tættere på en virkelighed uden for skolen på diskuteredes allerede i 2013 i en række artikler i bogen Skolen i virkeligheden (Hyllested \& Rasmussen, 2013), og opstillingen af en skolevirkelighed over for en 'virkelig' virkelighed diskuteres af Knudsen et al. (2017).

Ligeledes har det været undersøgt, hvilken form for didaktik der er tale om, når man arbejder med åben skole, og hvordan man kan styrke skolernes samarbejde med det omkringliggende samfund, ofte baseret på teoretiske overvejelser og i nogle tilfælde på empiriske interventionsstudier (se fx. Andersen \& Havgry, 2016; Knudsen, 2016; 2020a; 2020b; Shakoor \& Haastrup, 2016). En række artikler og bøger har beskrevet og diskuteret især skolens samarbejde med og omkring kunst og museumssamarbejde samt samarbej- 
der mellem museer, skoler og læreruddannelser (Knudsen \& Olesen, 2017; Seligmann, 2014; Thorhauge, 2014; Thorhauge \& Christensen, 2018). Dette har også været undersøgt internationalt med fokus på dannelsesaspektet (Hein, 2012; Hooper-Greenhill, 2007). Formålet med åben skole som en del af den dannelse, folkeskolen skal bidrage til, har været en del af mange forskellige undersøgelser og projekter, og de fleste konkluderer, at åben skole bidrager til elevens dannelse til demokrati (Buch et al., 2018; 2020; Hammershøj, 2020; Jensen, 2020; Knudsen et al., 2017; Satttrup \& Knudsen, 2020; Schilhab, 2017; Østergaard \& Gerlach, 2016).

Inden for de sidste par år har der også været udført nogle afdækninger af skolernes arbejde med åben skole. Det drejer sig bl.a. om Danmarks Evalueringsinstituts rapport fra 2018, der viser, at over halvdelen af lærerne nu har taget åben skole til sig (Danmarks Evalueringsinstitut, 2018a), og Koras rapport fra 2017 om implementering og effekt af reformens mange tiltag, der viser, at samarbejdet især er implementeret i forhold til kulturinstitutioner og foreninger, mens samarbejdet med erhvervslivet endnu kun er igangsat få steder (Jacobsen et al., 2017). Statusrapporten viser desuden, at det stadig opleves som vanskeligt at implementere åben skole, og at det er en hjælp, hvis kommunerne etablerer muligheder, skolerne kan benytte sig af (Undervisningsministeriet, 2018). Dette viser, at undersøgelser af, hvilke tiltag kommunerne har i forbindelse med arbejdet med åben skole, er nødvendige for at få et overblik over, hvorledes kommunerne understøtter implementeringen af den åbne skole. Det kan være et vigtigt tiltag, at kommunerne aktivt går ind $i$ at skabe kontakter til den omkringliggende verden og $i$ at tilrettelægge muligheder, lærerne kan benytte sig af, hvis man vil udvikle åben skole-mulighederne i kommunerne. Der er imidlertid ikke lavet undersøgelser af, hvordan kommunerne rent faktisk arbejder med at implementere den åbne skole, og netop kommunernes indsats er afgørende for lærerens muligheder for at gennemføre åben skole-tiltag.

På den baggrund ønskedes undersøgt, hvordan åben skole er etableret i kommunerne i en region, hvordan mulighederne kan karakteriseres inden for forskellige typer af samarbejder, samt hvor mange forskellige typer af samarbejdsmuligheder der rent faktisk er i kommunerne. Kommunernes forskellige tiltag ønskedes undersøgt - også i forhold til hinanden - gennem en analyse af deres tilbud på hjemmesider og interviews med centrale personer ansat i kommunerne ud fra følgende undersøgelsesspørgsmål: 
Hvilke strategier og tiltag omkring åben skole findes i en region, hoordan præsenterer kommunerne i regionen deres tiltag, og hoordan kan disse karakteriseres?

I det følgende redegøres for den metodiske tilgang og fund, og disse diskuteres før en konklusion.

\section{Metode, metodologisk baggrund og datagrundlag}

Denne artikel er baseret på data indsamlet i region Sjælland i forår, sommer og efterår 2019. Kondenseringsarbejdet og analyserne er gennemført i perioden december 2019 til februar 2020. Der kan være sket mere i kommunerne siden dataindsamlingen, og derfor er kommunerne anonymiseret $\mathrm{i}$ artiklen, bortset fra enkelte cases, der bruges som eksempler.

Afdækning af offentlige tiltag og handlinger kan udføres som dokumentanalyse med opmærksomhed på kriterier for udvælgelse, adgang og den systematiske analyse (Lynggaard, 2015). I studiet undersøges kommuners egen præsentation af deres åben skole-tiltag gennem indsamling af data på kommuners hjemmeside om åben skole. Sådanne dokumenter afspejler en samtidighed i forhold til tiltag, dvs. man kan undersøge situationen i det øjeblik, man læser dokumenterne, ud fra en antagelse om, at hjemmesiderne opdateres i forhold til nye tiltag, idet de også udgør lærernes adgang til kommunale tiltag. Ved at undersøge hjemmesiderne får man altså adgang til dokumenter af sekundær karakter (Lynggaard, 2015) samt dokumenter, som lærerne har adgang til og bruger som deres indgang, og som samtidig var mulige at tilgå for forskere. Hjemmesiderne linkede i visse tilfælde videre til andre sider, som også blev inddraget, en form for tilpasset sneboldsmetode (Aarhus Universitet, 2021). Med brug af dette kriterium for valg af dokumenter til analyse fokuseres på kommunernes eget udsagn om deres tiltag, hvilket også netop er det, der ønskes undersøgt.

Data er derfor indsamlet kvalitativt gennem en afsøgning af alle hjemmesider for alle kommuner i Region Sjælland og gennem semistrukturerede interviews med nøglepersoner i kommunerne.

På hjemmesiderne afdækkes kommunens strategi for åben skole sammen med de tiltag, der ligger tilgængeligt på hjemmesiden. Hjemmesiderne er undersøgt for samarbejdsrelationer, kommunale tiltag, tiltagenes karakter i forhold til formalisering og volumen, muligheder for at interagere med hjemmesiderne i form af tilmeldinger, oplysninger om deltagelse, mulighe- 
der for samarbejde osv. for både foreninger, institutioner, virksomheder og erhvervsliv og for lærerne. Links, der førte videre til uddybninger og specifikationer af tiltag, blev fulgt og inddraget, ligesom links, der førte til kommunale beslutninger mv., også inddragedes.

Der blev desuden afsøgt, om den enkelte kommune har en særlig kontaktperson, koordinator eller lignende, der er ansvarlig for arbejdet med åben skole i kommunen.

Lynggaard anfører, at dokumentindsamlingen med fordel kan suppleres af det eksplorative interview, der kan give yderligere oplysninger om relevante dokumenter, tiltag og handlinger, der bør inddrages under afdækningen af et felt (Lynggaard, 2015). Målet med interviewene var altså at sikre en mere dækkende vidensindsamling og ikke informantens personlige oplevelser med åben skole. Derfor blev interviewguiden også udformet i forhold til det at afdække, hvilke strategier og tiltag der findes, og hvordan de kan karakteriseres.

Karakteristikken af tiltagene er opdelt i forhold til tidligere kategoriseringer af åben skole-tiltag italesat i bekendtgørelsen: "virksomheder, institutioner for erhvervsrettet uddannelse, lokalsamfundets kultur-, folkeoplysnings-, idræts- og foreningsliv og kunst- og kulturskoler, med lokale fritids- og klubtilbud og med de kommunale eller kommunalt støttede musikskoler og ungdomsskoler" (Bekendtgørelse af lov om folkeskolen, 2017). Interviewspørgsmål blev derfor udformet på baggrund af disse kategorier og indeholdt nogle få, brede spørgsmål som oplæg til et semistruktureret interview af eksplorativ karakter, velegnet til at undersøge spørgsmål af typen 'hvad' (Lynggaard, 2015; Tanggaard \& Brinkmann, 2015). Således medførte forskningsspørgsmålet omkring tiltag og strategier spørgsmål som: "Har kommunen en strategi for åben skole-tiltag?" og " Er der overordnede kommunale tiltag?" Spørgsmål var primært af typen direkte spørgsmål, der spurgte til konkrete tiltag og strategier, og specificerende spørgsmål, der søgte uddybning af de direkte spørgsmål. Under interviewet blev der fulgt op med opfølgende spørgsmål, der søgte yderligere viden, der ikke var taget højde for i interviewguiden (Tanggaard \& Brinkmann, 2015). Interviews blev, af praktiske årsager, gennemført som telefoninterviews. Interviews er delvist transskriberet og kodet i forhold til forskningsspørgsmålet.

De identificerede kontaktpersoner i kommunerne blev inviteret til et telefoninterview på baggrund af interviewguiden.

Der er forsøgt indsamlet data fra samtlige 17 kommuner i Region Sjælland. Tre kommuner havde ikke nogen kontaktperson på hjemmesiden, og 
det har heller ikke været muligt i undersøgelsesperioden at finde en kontaktperson ved henvendelse til kommunens forvaltning, lokale politikere mv. I alt er der gennemført telefoninterview med 14 personer. For en enkelt kommune har vi hverken kunnet finde en særlig hjemmeside om åben skole eller en kontaktperson, og den kommune er derfor taget ud af undersøgelsen. I alt indgår derfor 16 kommuner.

Data, både interviewdata og dokumentdata, er efterfølgende kondenseret i notater. Kondenseringen foregik efter en analytisk-deduktiv metode, dvs. at der som udgangspunkt blev brugt kategorisering af tiltag og strategier fra bekendtgørelsen, som blev samlet under større overkategorier. Samtidig pegede analysen af datamaterialet også på overordnede kategoriseringer, der var interessante at gå videre med (Lynggaard, 2015). Forskningsspørgsmålene samt den indsamlede empiri førte til, at data blev kategoriseret i forhold til tre centrale forhold omkring en mere overordnet beskrivelse af kommunale strategier, tilgange og måder at arbejde med åben skole på. Disse tre centrale forhold er viden om:

- kommunernes strategi for åben skole

- kommunernes overordnede tiltag

- formalisering af samarbejde med omverdenen

Kategoriseringen af strategier er samlet under fire hovedkategorier med en række underkategorier udformet med baggrund i bekendtgørelsen (Bekendtgørelse af lov om folkeskolen, 2017) og empirien selv i overensstemmelse med den analytisk-deduktive tilgang (Lynggaard, 2015). Dette beskrives nærmere under Resultater, idet vi anser kategoridannelsen som en del af analysearbejdet. De indsamlede data er dernæst fremstillet kvantitativt og beskrevet deskriptivt, og efterfølgende er nogle tiltag uddybet med konkrete, korte casebeskrivelser eller eksempler.

\section{Resultater}

Første bearbejdning af data bestod i at danne kategorier til at skabe et overblik over de forskelligartede data. Analysen af hjemmesider og interviews er samlet under kategorier for åben skole-samarbejde. Disse er, som tidligere nævnt, dels baseret på, hvad der er fundet i empirien, men også på, hvilke former for samarbejde der nævnes i bekendtgørelsen. Her fremgår det, at skolen skal samarbejde med fx "...virksomheder, institutioner for erhvervs- 
rettet uddannelse, lokalsamfundets kultur-, folkeoplysnings-, idræts- og foreningsliv og kunst- og kulturskoler, med lokale fritids- og klubtilbud og med de kommunale eller kommunalt støttede musikskoler og ungdomsskoler..." (Bekendtgørelse af lov om folkeskolen, 2017). Sammenholdt med empirien er skolernes samarbejde derfor kategoriseret i fire hovedkategorier. De fire kategorier er:

1. Kulturinstitutioner, det kan fx være museer og lokale teatre eller samarbejde med kirker og biblioteker

2. Naturforeninger eller -institutioner som naturskoler og -vejledere

3. Lokale foreninger som idrætsforeninger eller musikskoler

4. Det private erhvervsliv, herunder også samarbejdet omkring erhverv med fx erhvervsskoler.

Under hver hovedkategori er der desuden, på baggrund af empirien, dannet underkategorier, der kan specificere typen af samarbejde under en hovedkategori.

Hovedkategorier og underkategorier fremgår af tabel 1.

I opgørelsen er derfor medtaget alle de former for samarbejde, der er fundet enten på hjemmesiden for/om åben skole eller via interview med en kontaktperson.

Datakondenseringen er kvantificeret og resultatet fremgår af tabel 1.

Tallene er opgjort i forhold til de forskellige kategorier og underkategorier på den måde, at der er noteret "1" for tilstedeværelse af et tiltag i en underkategori, mens et blankt felt betyder ikke-tilstedeværelse. Dernæst er der noteret "1" for tilstedeværelse af en eller anden form for underkategori af samarbejde i forhold til de fire hovedkategorier, blankt felt for ikke-tilstedeværelse. På den måde kan vi både se, hvilke kommuner der har tiltag inden for hver af de fire hovedkategorier Kultur, Natur, Foreninger og Erhvervsliv samt se, hvilke kommuner der har et tiltag inden for en af underkategorierne.

Endelig har vi lavet en opgørelse på kommuneniveau i form af en udregning af antallet af forskellige tiltag pr. kommune pr. hovedkategori.

Enkelte steder fremgår det ikke tydeligt af empirien, hvilken form for samarbejde under en hovedkategori der er tale om, og der er derfor blot noteret "1" under hovedkategorien. 
Tabel 1. Typer af samarbejde i kommunerne i Region Sjælland

Kommunerne er benæont med tal fra 1 til 17. Kommune fem er der ingen resultater fra.

\begin{tabular}{|c|c|c|c|c|c|c|c|c|c|c|c|c|c|c|c|c|c|c|}
\hline Kommune nr. & 1 & 2 & 3 & 4 & 5 & 6 & 7 & 8 & 9 & 10 & 11 & 12 & 13 & 14 & 15 & 16 & 17 & 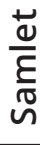 \\
\hline Kultur & 1 & 1 & 1 & 1 & & 1 & 1 & 1 & 1 & 1 & 1 & 1 & 1 & 1 & 1 & 1 & & 16 \\
\hline lokale museer & & 1 & & & & 1 & 1 & & & & 1 & 1 & 1 & & & 1 & & 7 \\
\hline biblioteker & & 1 & & 1 & & & & & & & 1 & & 1 & & & & & 4 \\
\hline teatre & 1 & & & & & & 1 & & & & & & & & & & & 2 \\
\hline kunst (huskunstner) & & & 1 & & & & 1 & 1 & & & & & & & & & & 3 \\
\hline Kirker & & & & & & & & & & & 1 & & 1 & & & & & 2 \\
\hline Natur & & & & 1 & & 1 & 1 & & 1 & 1 & 1 & 1 & 1 & & & 1 & & 9 \\
\hline naturskole & & & & 1 & & 1 & & & & & & & & & & & & 2 \\
\hline naturvejleder & & & & & & & & & & & & & & & & & & 0 \\
\hline andet & & & & & & & 1 & & & & & & & & & & & 1 \\
\hline Foreninger & 1 & 1 & & 1 & & 1 & 1 & & 1 & 1 & 1 & 1 & 1 & & & 1 & 1 & 12 \\
\hline musikskole & 1 & 1 & & & & & 1 & & & & 1 & & & & & & 1 & 5 \\
\hline idræt/sport & 1 & 1 & & 1 & & 1 & 1 & & 1 & 1 & 1 & 1 & 1 & & & 1 & & 11 \\
\hline ungdomsskoler mv. & & & & & & & & & & & 1 & & & & & & & 1 \\
\hline Erhverv & 1 & & & 1 & & 1 & 1 & 1 & 1 & & & 1 & 1 & 1 & & 1 & 1 & 11 \\
\hline større virk. & 1 & & & & & & & & & & & & & 1 & & & & 2 \\
\hline DI/DB & & & & 1 & & & 1 & & 1 & & & & 1 & 1 & & 1 & & 6 \\
\hline lokale virk. & & & & 1 & & 1 & 1 & & 1 & & & 1 & 1 & 1 & & & 1 & 8 \\
\hline eud/andre erhv.udd. & & & & & & & 1 & & 1 & & & 1 & 1 & & & & 1 & 5 \\
\hline sum & 3 & 2 & 1 & 4 & 0 & 4 & 4 & 2 & 4 & 3 & 3 & 4 & 4 & 2 & 1 & 4 & 3 & \\
\hline
\end{tabular}

Af tabel 1 fremgår, at der først og fremmest finder et samarbejde sted mellem skolerne og de lokale kulturinstitutioner. Alle 16 kommuner samarbejder i et eller andet omfang med lokale kulturinstitutioner. Flest samarbejder med lokale museer (7), dernæst følger samarbejde med folkebiblioteker (4). Samarbejderne kan være mere eller mindre formaliserede og afprøvede. Ofte fremgår de på kommunernes hjemmesider som muligheder, skolerne kan benytte sig af, men der er også kommuner, der har et mere formelt samarbejde, der forpligter skolerne til at benytte sig af varierende tilbud på forskel- 
lige klassetrin. Samarbejde med et teater er betinget af, at der findes et sådant i lokalområdet, og her nævner to kommuner et samarbejde med teatre, ligesom to kommuner samarbejder med en lokal kirke. Tre kommuner nævner et samarbejde med en kunstner gennem huskunstnerordningen.

Det kan fortolkes således, at samarbejdet med lokale kulturinstitutioner formentlig har været det, der har været lettest at starte med for kommunerne, da mange af institutionerne allerede i forvejen har haft skoletjenester eller andre former for samarbejde med skolerne (Andersen \& Havgry, 2016). Museerne har generelt været gode til at få oprettet og formaliseret tilbud til skolerne (Johnsen \& Andersen, 2019a), og det ses også i vores resultater. Resultatet er i overensstemmelse med det resultat, EVA har fået i deres kortlægning af åben skole-arbejdet fra 2018 (Danmarks Evalueringsinstitut, 2018a). Her viser de, at 49 procent af alle lærere har samarbejdet med en kulturinstitution omkring undervisning det seneste år og 8 procent med en kirke eller præst. Det viser, at lærerne benytter de tilbud, der er, og at man kan betegne kulturinstitutionernes mange åben skole-tiltag som succesfulde også her i Region Sjælland.

Samarbejdet med lokale foreninger og samarbejdet med erhvervslivet er de to kategorier, der er næstmest beskrevet som mulige samarbejder i kommunerne.

12 kommuner har nævnt, at de samarbejder med lokale foreninger. Samarbejdet med lokale foreninger er typisk et samarbejde med lokale sports- og idrætsforeninger, idet 11 ud af de 12 kommuner, der samarbejder med lokale foreninger, beskriver et sådant samarbejde. Samarbejde med musikskolen har i alt fem kommuner beskrevet, mens et samarbejde med ungdomsskolen findes beskrevet i en enkelt kommune.

Ifølge EVAs kortlægning (2018) angiver 25 procent af lærerne, at de har samarbejdet med en lokal idrætsforening det seneste år, og 12 procent har samarbejdet med musikskolen (Danmarks Evalueringsinstitut, 2018a). Lærerne selv siger altså, at de ikke samarbejder så meget med de lokale foreninger, som kommunerne i Region Sjælland i hvert fald lægger op til og forventer. Det kan være, fordi disse samarbejder i højere grad skal 'løbes i gang' af lærerne selv, samt at dette samarbejde i nogen grad vanskeliggøres af, at mange foreninger drives af frivillige, der ikke har mulighed for at deltage $i$ et samarbejde inden for normal skoletid. Dette understøttes af Koras rapport om implementeringen af en længere og mere varieret skoledag fra 2017 (Jacobsen et al., 2017). 
Samarbejdet med erhvervslivet er bedre repræsenteret end forventet, da tidligere undersøgelser viser, at det er noget, der har været sværere at komme i gang med (Jacobsen et al., 2017). Blandt andet opleves det som mere krævende af den enkelte lærer både at organisere og vedligeholde kontakter og samarbejder.

I region Sjælland ses, at 11 kommuner har beskrevet en eller anden form for formaliseret samarbejde med erhvervslivet eller erhvervslivets organisationer. Det er især de mindre, lokale erhvervsdrivende, der samarbejdes med, idet otte kommuner har beskrevet et sådant samarbejde. Den slags samarbejder kan fx være et samarbejde med en lokal tømrer om et mindre byggeprojekt på legepladsen eller opholdsarealer på skolen. Samarbejdet med de store organisationer som Dansk Industri og Dansk Byggeri svarer seks kommuner, at de har i en eller anden grad, mens fem kommuner beskriver et samarbejde med erhvervsuddannelserne. Nogle samarbejder er samarbejder med kommunale virksomheder, hvilket forventeligt gør det lettere at etablere kontakt mellem skoler og virksomheder, da kommunale virksomheder må antages at blive inddraget $\mathrm{i}$ åben skole-arbejdet, det kan fx være et lokalt renovationsfirma.

At erhvervssamarbejdet har oplevet en vækst, siden det i 2017 blev understreget, at kommunerne skal samarbejde med erhvervslivet (Danmarks Evalueringsinstitut, 2018b), understreges også af EVAs kortlægning (2018), der viser, at 35 procent af lærere og pædagoger har haft et samarbejde med erhvervsvirksomheder, og 13 procent har samarbejdet med erhvervsskolerne. Endelig ser vi, at to kommuner samarbejder med større virksomheder. Vores undersøgelse viser altså, at 11 af kommunerne har beskrevet et formaliseret samarbejde med erhvervslivet i en eller anden form, og EVAs landsdækkende kortlægninger viser, at lærerne også gennemfører sådanne samarbejder. Samtidig peger Nationalt netværk af skoletjenester på, at det er en fordel, hvis kommunerne engagerer sig i dette arbejde, da det kræver vedligeholdelse, og kommunerne anbefales også forskellige modeller for dette (Johnsen \& Andersen, 2019b).

Samarbejdet kan have mange former; i nogle kommuner inviteres det lokale erhvervsliv og de store organisationer til en markedsdag, hvor de kan præsentere sig selv og mulige samarbejder for lærere og skoleledere, andre steder har man en slags projektbank, hvor virksomheder kan lægge forslag til samarbejder eller projekter med udgangspunkt i virksomhedens produkter ind, som skolerne kan gå i gang med. Det kan fx være et arbejde med 
matematiske mønstre med udgangspunkt i forskellige typer af betonfliser præsenteret af en større virksomhed med produktion af betonvarer.

EVAs kortlægning har ikke kategoriseret samarbejdet med fx naturcentre og -vejledere som en selvstændig kategori, men har i stedet kategoriseret det som 'andet'. Nærværende undersøgelse viser, at denne form for samarbejde er beskrevet i ni kommuner i regionen, altså i lidt over halvdelen af kommunerne. I to kommuner er det et samarbejde med naturcenteret, der omtales. Det kan bero på, at især kommuner, der har relativt let transport til en naturskole, har et formaliseret samarbejde med dem. Transport til en institution eller organisation spiller en stor rolle for samarbejdsmulighederne, idet en lang og/eller dyr transport kan være en hindring for et samarbejde, viser tidligere undersøgelser (Andersen \& Havgry, 2016; Jacobsen et al., 2017). Der omtales desuden andre former for samarbejde baseret på naturoplevelser, fx Nationalpark Skjoldungernes land, som vi omtaler i en casebeskrivelse senere i artiklen.

\section{Omfanget af tiltag i den enkelte kommune}

Ser man på kommunernes forskellige tiltag, ser vi, at kommunerne har vægtet tiltag inden for de fire kategorier forskelligt, ligesom der er stor for-

Figur 1. Hvor mange typer af samarbejde har kommunerne?

\section{Antal kommuner, der har beskrevet samarbejde inden for hhv. 1, 2, 3 eller 4 kategorier}

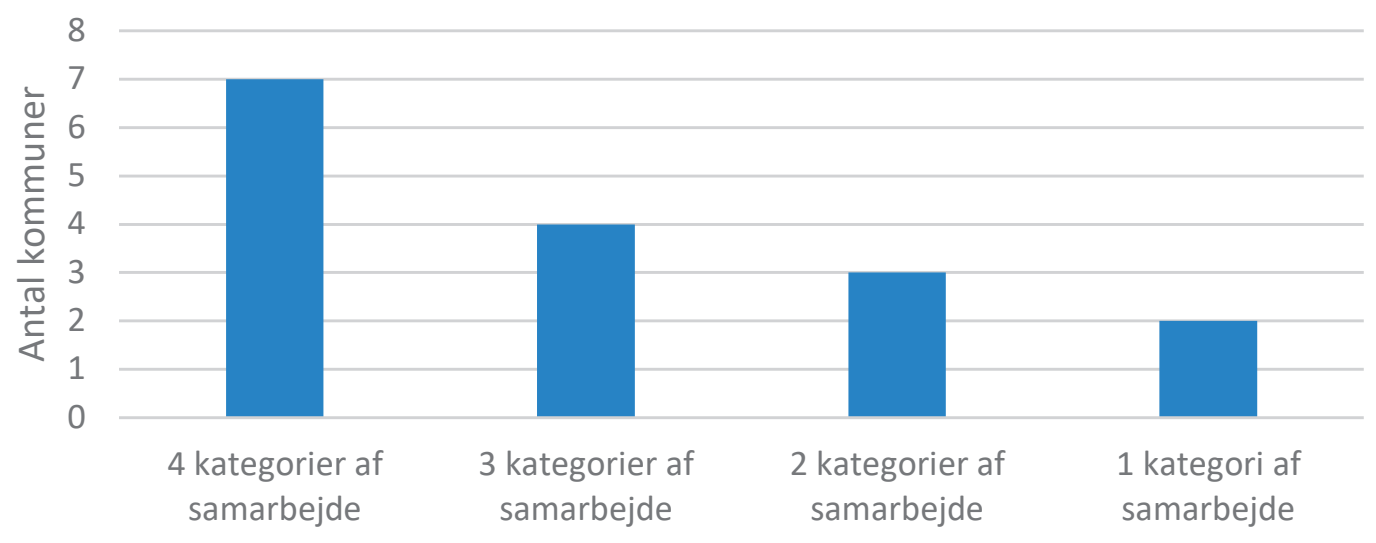


skel på, hvor mange kategorier en kommune så at sige 'dækker' (Kultur, Natur, Foreninger og Erhvervsliv). I alt har syv kommuner ud af de 16 inddragede kommuner i undersøgelsen beskrevet et samarbejde inden for alle fire kategorier, fire kommuner har et samarbejde inden for tre af de fire kategorier, vi har defineret, tre kommuner inden for to af dem, og to kommuner har nævnt eller omtalt et samarbejde inden for blot en af de fire kategorier. Der er altså en ret stor spredning, hvad angår de forskellige beskrevne tiltag inden for de fire opstillede kategorier (figur 1). Samtidig ses dog, at der er et flertal af kommuner, der har tiltag inden for alle fire kategorier.

\section{Strategi, tiltag og formalisering}

I Region Sjælland har 10 ud af de 16 kommuner en kommunal strategi for arbejde med åben skole (februar 2020). Det er rimeligt at antage, at dette tal kan have ændret sig siden dataindsamlingen, da der i interviewperioden var flere kommuner, der gav udtryk for, at der blev arbejdet konkret på at få lavet egentlige strategier for skolernes arbejde med åben skole. Det viser, at kommunerne er på vej i forhold til at implementere den åbne skole, og at dette arbejde stadig er igangværende.

Der ses umiddelbart stor variation i den praksis, hvormed der arbejdes med åben skole, i forhold til, hvor høj grad af central styring, målsætning og omfattende strategi kommunen har iværksat. I nogle kommuner i regionen er der udførligt beskrevet, hvordan skolerne skal arbejde med området, og i andre lægges der op til en mere decentral indfaldsvinkel, hvor skolerne selv forestår kontakt og afvikling af diverse samarbejder. I nogle kommuner er der således tale om, at skolerne skal gennemføre visse forløb omkring åben skole, mens det $\mathrm{i}$ andre er helt frivilligt, om skolerne vil benytte sig af tilbuddene, der evt. ligger som en 'bank' på hjemmesiden. Vi ved dog, at det er vigtigt, at kommunen har gjort en del forarbejde, for at lærerne kan arbejde målrettet og systematisk med at inddrage det omkringliggende samfund (Undervisningsministeriet, 2018), og derfor kan det, at man laver en forpligtelse til at bruge det materiale og de etablerede kontakter, der er udarbejdet i samarbejde med kommunen, understøtte arbejdet med åben skole-tiltag. I syv ud af de 16 kommuner har man bestemte tiltag, skolerne skal implementere i undervisningen. Det kan fx være, at alle elever på et bestemt klassetrin skal besøge et bestemt museum eller deltage i et samarbejde med en lokal idrætsforening. En enkelt kommune har en egentlig dannelsesrygsæk, som alle elever (fra vuggestue til 9. klasse) skal igennem. Sådanne formali- 
seringer af samarbejdet styrker kommunernes åben skole-tiltag og sikrer et systematisk og vedholdende arbejde med åben skole, men kræver også, at lærerne har tiden til at forberede arbejdet og kan se den didaktiske mening med de tiltag, der er placeret på de enkelte klassetrin.

\section{Diskussion}

Denne undersøgelse viser, at der i Region Sjælland frem til februar 2020 er beskrevet en del samarbejde med forskellige aktører uden for skolen i overensstemmelse med åben skole-bekendtgørelsen. Det er seks år siden, reformen blev igangsat, og det ses, at kommunerne i Region Sjælland er i gang med at implementere denne del af reformen. Især samarbejder, der umiddelbart er lette at gå til, fylder meget på kommunernes hjemmesider og $\mathrm{i}$ interviews med kommunale aktører. De mest hyppige er samarbejdet med kulturinstitutioner, herunder især lokale museer og biblioteker. Disse samarbejder har formentlig, for en dels vedkommende, været i gang også før reformen, ligesom museerne selv har spillet en stor rolle i form af etableringen af bedre og mere udfarende skoletjenester. Det er vigtigt, at samarbejdet bidrager til skolens formål, da skolen jo altid er underlagt dette, og at både lærere og museer er opmærksomme på dette.

\section{De enkelte kommuners strategi for åben skole}

Kommunerne griber opgaven meget forskelligt an især med fokus på, hvor forpligtende samarbejdet med omkringliggende institutioner, foreninger og erhvervslivet er.

Fx har en af kommunerne fokus på kultur og dannelse og har i den forbindelse klare forventninger til inddragelse af eksterne videnspersoner og institutioner i et nærmere angivet omfang fra vuggestue til udskoling. Dette er udførlig beskrevet i strategien, og skolerne er forpligtede på at samarbejde med og besøge bestemte institutioner. Andre steder opererer man primært med, at tilbuddene skal opfattes som en slags tilbudskatalog eller inspirationskatalog over muligheder, som lærerne kan vælge mellem, og atter andre steder har man en kombination af begge dele. Dvs. der er tiltag, skolerne skal deltage i, og tiltag, de kan vælge at inddrage i deres undervisning. Centrale krav om at skulle implementere bestemte forløb i sin undervisning betyder, at lærerne skal kunne tilpasse forløb til deres øvrige undervisning, uanset om det didaktisk er meningsfyldt eller ej, og det er problematisk ud fra et didaktisk perspektiv. Undervisning skal helst vælges ud fra den lærings- 
mæssige værdi, det har i en konkret didaktisk situation, og ikke ud fra, at en kommunal strategi siger, at der netop på et bestemt klassetrin skal besøges et bestemt museum, hvis man skal begrunde det didaktisk. Omvendt er en sådan 'skal'-opgave med til at sikre, at skolerne i kommunen rent faktisk får arbejdet med åben skole. Samtidig fremhæves det i et nyudgivet review, at det er vigtigt at vide, hvem der har ansvaret for åben skole-samarbejder, og her vil en forpligtelse i hvert fald vise, at ansvaret for at tilrettelægge en åben skole-strategi ligger hos kommunen, mens ansvaret for at gennemføre dem er udlagt til skolen og i praksis den enkelte lærer (Rosenbäck \& Knudsen, 2020). Der er således argumenter både for og imod sådanne forpligtende tiltag.

Endvidere er der kommuner, der har et gennemarbejdet forslag til, hvordan en 'læseplan' for åben skole kan se ud, men hvor det i sidste ende er skolerne, der, i samarbejde med partnere, udarbejder en plan for forløbet. Dvs. at kommunen $\mathrm{fx}$ angiver, på hvilket tidspunkt i skoleforløbet, det er oplagt at arbejde med de forskellige tiltag, kommunen har tilbud om, men skolerne tilrettelægger og vælger selv.

I flere interviews sondres der mellem på den ene side samarbejder, der faciliteres eller ligefrem pålægges skolerne af kommunen, og på den anden side de initiativer, lærerne selv skal igangsætte og drive. Tidligere undersøgelser viser, at bliver det for krævende at etablere og vedligeholde kontakt, kan lærerne ikke nå det i en i øvrigt travl hverdag. På den anden side har vi selv i et tidligere projekt erfaret, at nogle skoler har så mange forskellige initiativer, at det næsten er svært at finde en uge med helt almindelig undervisning (Buch et al., 2018; Jakobsen et al., 2017). Og ingen af delene er hensigtsmæssige.

En kommunal strategi kombineret med et veludbygget og formaliseret samarbejde med en bred vifte af tilbud, lærerne kan se værdien af i deres daglige undervisning, er en god måde at sikre skolernes arbejde med åben skole på. Det kan understøtte den undervisning, lærerne har tilrettelagt. En stærk kommunal strategi og en række muligheder, der ikke kræver for meget forberedelse, og som vedligeholdes af en kontaktperson i kommunen, vil styrke åben skole, da der er for meget arbejde i at gøre dette for den enkelte lærer, der har en række andre undervisningsopgaver ved siden af. Som tidligere nævnt har nogle kommuner en gennemarbejdet strategi med enten en række samarbejder, der skal gennemføres på forskellige klassetrin, eller med forslag til, hvornår de forskellige tilbud, kommunen har tilrettelagt, kan bruges optimalt i skoleforløbet. Begge dele er med til at fremme 
åben skole-arbejdet, som to af vores kontaktpersoner og informanter fra disse kommuner fremhævede. Men langt fra alle kommuner havde sådan en strategi. Formentlig har tilstedeværelsen af en egentlig kommunal strategi ændret sig i nogle kommuner, siden data blev indsamlet til denne undersøgelse, hvorfor vi ikke vil sige så meget mere om dette.

\section{Deltagelse i udviklingsprojekter som en måde at udvikle åben skole på}

Nogle kommuner har satset meget stærkt på åben skole og har eller er i gang med at gennemføre udviklingsprojekter på området. Et eksempel er det store projekt Bliv Skjoldunge i Lejre Kommune. Tiltaget omfatter en indsats, der breder sig over flere af de ovenstående kategorier, idet der både inddrages natur- såvel som kulturformidling i projektet. Vi har fulgt projektet Bliv Skjoldunge i Nationalpark Skjoldungernes land, som er et konkret eksempel på, hvordan man kan udvikle et åben skole-tilbud i samarbejde med en lokal, ekstern aktør (Nationalpark Skjoldungernes land, u.å.). Projektet inddrager mange klasser og mange lærere og er desuden knyttet til andre kommunale projekter. På den måde opnår kommunen en synergieffekt, i og med lærernes viden kan bruges i flere tiltag (udsagn fra lærer i projektet).

Projektet omfatter forløb i naturen, fx i nationalparkens skove og kystområder, med fokus på biodiversitet, fugle, fisk og friluftsliv, og forløb knyttet til kulturhistoriske elementer i nationalparken gennem samarbejde med eksempelvis Vikingeskibsmuseet og Lejre Museum. I samarbejde med Lejre Kommune har nationalparkens formidlingskoordinator og to naturvejledere gennemført en række pilotforløb i efteråret 2019. Kommunens Grøn generations-lærere, en anden kommunal indsats (Lejre Kommune, u.å.), har deltaget med klasser og i den forbindelse også bidraget til udviklingen gennem bl.a. evalueringer og interviews. Initiativet til samarbejdet kommer fra nationalparken; kommunen er altså ikke initiativtager, men qua fokus på åben skole og den organisering, der ligger i projekt Grøn generation, har det været ligetil at indgå den samarbejdsaftale, der ligger til grund for deltagelsen i udviklingsprojektet. På den måde sikres kvaliteten af åben skole-tilbuddet og lærernes ejerskab til projektet, når det bliver endeligt implementeret, hvilket også er vigtigt (Buch et al., 2018).

\section{Samarbejde med lokale foreninger}

Etableringen af samarbejde med lokale foreninger synes umiddelbart at lyde til at være enkelt at implementere, men her ses det, at der er knapt så mange kommuner, der har fået dette igangsat endnu (Kock, 2017). Det kan skyldes 
udefrakommende forhold, som $\mathrm{fx}$ at de frivillige, der ofte driver dette arbejde i foreningerne, ikke selv har tid til at indgå i skoletiden pga. eget arbejde. Dette kan afhjælpes ved, at kommunerne udlægger en mulighed for økonomisk kompensation til de frivillige, der bruger tid på et samarbejde med en skole, som man fx har forsøgt i Roskilde Kommune med positive resultater (Cowi, 2018). Omvendt kan mange af de aktiviteter, der umiddelbart findes i fx idrætsforeninger, meget let inddrages i idrætsundervisningen i skolen, og foreningerne har en interesse i at tiltrække interesserede børn og unge til netop deres forening (DGI, u.å.). Dermed kan et samarbejde således umiddelbart ses som en fordel for begge parter (Cowi, 2018). Igen må det være vigtigt, at samarbejdet ikke blot bliver en reklame for en bestemt forening, men at det rent faktisk har værdi i forhold til skolens og undervisningens formål, herunder også de overordnede formål (Cowi, 2018).

\section{Naturområdet}

I Region Sjælland, der er så rig på naturoplevelser, er der tilsyneladende ikke meget formaliseret samarbejde med naturinstitutioner. Det ville være forventeligt, at der var et sådant samarbejde i de fleste kommuner, fordi den slags samarbejde kendes fra tiden før reformen. Vi har selv kendskab til naturskoler i områderne qua vores eget arbejde som undervisere på en læreruddannelse og gennem vores egne casestudier (se tidligere i denne artikel fra fx Lejre Kommune), og vi ved fra tidligere undersøgelser, at netop naturområdet har spillet en stor rolle i den tidlige åben skole-strategi i landet (jf. fx Hyllested og Rasmussen, 2014). Derfor undrer vi os over, at der ikke nævnes flere af den slags tiltag i vores undersøgelse. En mulighed kan faktisk være, at flere kommuner ikke nævner netop et samarbejde med naturskolen, fordi det er en allerede indarbejdet og en så fasttømret del af skolens undervisning, at det derfor nærmest overses. I hvert fald finder vi det underligt, at selv institutioner, fx naturskoler, der er kendte, ikke er nævnt af kommunerne.

\section{Samarbejde med erhvervslivet og erhvervsskolerne}

Samarbejdet med erhvervslivet har fået særlig bevågenhed, i og med det er blevet en forpligtelse for skolerne at samarbejde med erhvervslivet og erhvervsuddannelserne (Danmarks Evalueringsinstitut, 2018b). Undersøgelsen viser, at det også er slået igennem i Region Sjælland. Mange kommuner har en række nyudviklede tiltag inden for denne kategori af samarbejde. Denne del af åben skole har været sværere at implementere, men kommu- 
nerne i Region Sjælland er i gang. Hindringerne kan her være, at virksomheder simpelthen ikke kan afsætte personale til at indgå som undervisere eller cases i skolerne. En af hindringerne kan også være, at de ønsker at tage sig betalt for det (Andersen \& Havgry, 2016). På den anden side viser undersøgelsen, at især mange lokale, mindre virksomheder i mindre samfund ser ud til at have etableret et fast samarbejde med en skole, og at de indgår i denne type samarbejde, fordi de opfatter sig som en del af lokalsamfundet. Det er noget, der bør undersøges nærmere. Hvordan etableres og vedligeholdes denne type af samarbejde, og hvilken værdi har det for eleverne og virksomheden? Nærværende undersøgelse svarer ikke på disse spørgsmål, men har afdækket, at der er flere konkrete eksempler på den type af samarbejde.

En del kommuner har afsat særlige beløb til netop dette samarbejde. I de kommuner, hvor der i indsamlingsperioden var etableret samarbejde eller var indsatser på erhvervsområdet, kommer disse indsatser til udtryk på forskellig vis. En del kommuner har ansat en 'erhvervsplaymaker', der skal styrke elevernes tilknytning til de lokale virksomheder og de karrieremuligheder, der kan ligge der. Her er således en dobbelt hensigt: den faglige læring, der kan være i læringsudbyttet for eleverne af samarbejdet, og den nytteværdi, der kan være for virksomheden i form af eventuelle fremtidige medarbejdere på området. Samtidig tyder det på en tæt dialog med de involverede virksomheder. Denne tætte dialog med lokale aktører på erhvervsområdet ses dog også i andre kommuner uden egentlig erhvervsplaymaker. Sådanne lokale virksomhedssamarbejder bør undersøges og følges nærmere med henblik på indsigt $i$, hvordan denne type af samarbejde etableres og vedligeholdes, samt hvilken værdi det har for eleverne og virksomheden.

Det typiske i disse samarbejder med virksomheder og erhvervsliv generelt vil være skolebesøg, hvor den daglige undervisning i skolen suppleres med indsigt i fx en bestemt produktion. Det kan være med til at give stor indsigt i, at det, der undervises i i skolen, faktisk bruges ude i 'den virkelige verden'. Der er således en grad af autenticitet i disse forløb. Det kunne være matematik i forbindelse med lokale byggerier eller udregning af $\mathrm{pH}$-værdier i forbindelse med kemisk produktion. Imidlertid er det som oftest korte endagsbesøg, der opereres med. Det ville måske være hensigtsmæssigt med flerårige forløb, så eleverne kommer ind under huden på den pågældende virksomhed (Vestergaard, 2016). 


\section{Går samarbejdet begge veje?}

Skoletjenester eksisterede på mange museer også før reformen, og en udvidelse eller styrkelse af samarbejdet med disse har været let at gå til for kommunerne (fx Thorhauge \& Christensen, 2018).

Man kan diskutere, om et for formaliseret skoletilbud i virkeligheden kommer til at ligne skolen så meget, at der ikke længere er tale om selve intentionen med den åbne skole, nemlig at undervisningen skulle være anderledes og give eleverne indblik i verden uden for skolen. Hvis det, der foregår på et museum, mimer en almindelig skoleundervisning, er det så åben skole, fordi det foregår i et (klasse)lokale på det lokale museum? Mange museer har ansat folkeskolelærere som formidlere og har tilrettelagt velafprøvede didaktiske forløb, der kunne være almindelige undervisningsforløb, ofte med tilknyttede læringsmål passende til læringsmål for udvalgte fag. Fordelen ved dette er, at der rent faktisk bliver et samarbejde, og at det er let for lærerne både at tilgå og se værdien af i en målorienteret skole, men ulempen er, at det er svært at skelne fra den traditionelle undervisning i klassen (jf. fx Villadsen, 2016). Samarbejdet bør gøres ud fra en forudsætning om at samarbejde om et fælles tredje (Holst, 2016). Fra en kommune uden for Region Sjælland er vi bekendt med et forløb, hvor skolen arbejder ind i eller sammen med et museum. Eleverne (4.klasse) blev inddraget $\mathrm{i}$ at udvikle et udstillingsrum for museet. Her gik samarbejdet således begge veje - også eleverne bidrog ind i opgaveløsningen. Man samarbejdede netop om et fælles tredje, et udstillingsrum skabt af elever på et konkret museum, noget, der skaber værdi for alle parter (Holst, 2016).

En diskussion af ovenstående problematikker, og hvad der egentlig ligger i begrebet åben skole, er væsentlig. Skal det være en slags envejskommunikation, hvor eleverne præsenteres for eksempler på noget, der ikke foregår i skolen, men uden for den, eller skal det være noget, hvor der finder et egentligt samarbejde sted mellem skole og omverden, og hvor skolen også bidrager til udviklingen af omverdenen?

\section{Undersøgelsens muligheder og begrænsninger}

Denne undersøgelse har inddraget kommunernes egne udsagn om deres åben skole-tiltag gennem en analyse af kommunernes egne hjemmesider samt interview med en central informant fra hver kommune. Der er til dels søgt efter sneboldsmetoden, men der er ikke i særlig høj grad afsøgt fx politiske dokumenter, hvis de ikke fremgik af hjemmesiden. Undersøgelsen har fokuseret på, hvordan kommunerne selv præsenterer deres strate- 
gier og tiltag, hvorfor der ikke fx er spurgt nærmere ind til allerede kendte tiltag. Naturskolesamarbejderne er et eksempel på dette. Det betyder også, at vores samlede beskrivelser ikke er fuldstændige. Dette er til dels begrundet i forskningsspørgsmålet, der fokuserede på, hvad kommunerne selv oplister og præsenterer i forhold til åben skole. Undersøgelsen afdækker dermed kun det, kommunerne selv viser eller nævner, og det kan undre, at man ikke har sikret alle tiltag på hjemmesiderne. Dog kan meget af dette have ændret sig, siden undersøgelsen pågik.

Undersøgelsen har først og fremmest afdækket, hvilke tiltag og strategier der findes i regionen, og har ikke undersøgt, hvordan de rent faktisk fungerer, hverken gennem spørgsmål eller empiriske undersøgelser. Det ville være oplagt, på baggrund af denne undersøgelse, at lave eksplorative besøg i konkrete kommuner og skoler. En sådan undersøgelse ville kunne afdække, hvordan de kommunale tiltag fungerer, og hvordan de bliver brugt. Denne undersøgelse danner en god baggrund for at kunne dykke mere ned i konkrete tiltag, i og med den afdækker, hvad der findes - eller fandtes i den pågældende periode.

\section{Konklusion}

Vores undersøgelse viser først og fremmest, at skolerne i Region Sjælland er i gang i forhold til at implementere den del af folkeskolereformen, der handler om åben skole. Kommunerne gør det på en række forskellige måder, gående fra mindre, lokale initiativer til store, kommunale initiativer, der omfatter forpligtende deltagelse i en række tilbud hen over et skoleforløb, og der er store forskelle mellem kommunerne

Med afsæt i bekendtgørelsen er defineret fire kategorier af samarbejdsrelationer, Kultur, Natur, Foreninger og Erhvervslivet.

Undersøgelsen viser, at der er store forskelle på, hvor meget kommunerne er involveret $\mathrm{i}$ at skabe og vedligeholde kontakter til aktører inden for de fire kategorier af samarbejde, ligesom der er store forskelle på, hvor mange tilbud der er inden for de fire kategorier i hver kommune. Samarbejde med kulturlivet står stærkest med absolut flest beskrevne samarbejder, dernæst kommer erhverv og foreninger, mens samarbejde med naturforeninger er det, der nævnes færrest gange. Tidligere undersøgelser har vist, at der findes samarbejder, der ikke er blevet nævnt på hverken hjemmesider eller af informanter, så det formodes, at nogle af disse samarbejder enten er så indarbejdede i kommunerne, at man ikke tænker over, de findes, eller at 
man ikke regner dem med til åben skole (Buch et al., 2018). Særligt samarbejdet med erhvervslivet har været længe om at komme i gang, og det er på mange måder sikkert også det, der kræver mest af begge parter. Her er mere forskning nødvendigt, både for at udvikle på området, så det kan få en større plads i samarbejderne, og for at skabe et mere dialogisk samarbejde, hvor både skole og erhvervsliv kan profitere af det. Hvis samarbejdet særligt handler om korte besøg med indblik i, hvad der foregår på en virksomhed, er opgaven krævende for virksomhederne, der ikke får meget igen. Hvis eleverne kunne bidrage med nye, konkrete forslag til virksomheders faktiske udfordringer, ville fordelene måske gå begge veje.

Undersøgelsen viser, at hvor kommunerne har en strategi, er der ofte flere og mere stabile samarbejder og også flere såkaldt skal-opgaver for lærerne end der, hvor kommunen endnu ikke har en strategi. Det medfører både fordele og ulemper i form af flere arbejdsopgaver til lærerne, som skal få krævede tiltag til at passe ind i deres undervisning, men også i form af en sikring af det kontinuerlige arbejde.

Da dataindsamlingen afsluttedes, var flere kommuner i gang med at udvikle deres åben skole-strategi, så i skrivende stund forventes, at endnu flere kommuner har en sådan i dag.

Nogle kommuner har satset virkelig meget på at udvikle åben skole, både gennem en række formaliserede samarbejder, der ofte netop er lokalt forankrede, og ved at få midler til udviklingsarbejder. Den måde at gribe åben skole an på er med til at sikre både lokal forankring, lærerinvolvering og opkvalificering af de deltagende lærere foruden en høj kvalitet i de udviklede projekter og efterfølgende materialer. Et eksempel herpå er case-eksemplet Skjoldungernes Land.

Åben skole er krævende for lærere og skoler. Det kræver tid til forberedelse og implementering i den almindelige undervisning med mange krav og forventninger. Stærke kommunale strategier og indsatser, der understøtter lærernes arbejde, så en række praktiske ting er klaret på forhånd, gør det enklere for lærerne at bruge de tilbud, der er udviklet (Undervisningsministeriet, 2018).

Et andet relevant spørgsmål er, om kommunerne og skolerne er opmærksomme på, hvornår et tilbud rent faktisk er åben skole, og hvornår det snarere er skolen, der er flyttet ud i andre omgivelser. Den diskussion præger åben skole-debatten og er ikke kun gældende for kommuner og skoler i Region Sjælland. Her vil mere forskning være nødvendig, dels for at udvikle 
feltet, dels for at kunne bidrage mere ind i diskussionen om, hvad åben skole egentlig er for noget, og hvad den skal kunne.

Vores undersøgelse er fokuseret på Region Sjælland. Her ser vi, at regionens kommuner har lavet mange tiltag for at imødekomme reformens krav om en mere åben skole, men også, at nogle kommuner stadig mangler et stykke i at nå i mål.

Vores undersøgelse har ikke omfattet skolers og læreres konkrete brug af de mange tilbud, og mere forskning med fokus på, hvordan åben skole bruges og fungerer i praksis, ville bidrage yderligere til viden om, hvordan åben skole er implementeret $\mathrm{i}$ kommunerne.

\section{Referencer}

Andersen, M. D., \& Havgry, M. (2016). Tre udfordringer for den åbne skole - et statusbillede på den åbne skole anno 2016. Unge Pædagoger, 3, 38-49.

Aarhus Universitet. Metodeguiden. Snowball sampling. https://metodeguiden.au.dk/

Bekendtgørelse af lov om folkeskolen, LBK nr 1510 af 14/12/2017. https://www.retsinformation.dk/eli/lta/2017/1510

Brinkmann, S., \& Tanggaard, L. (2015). Kvalitative metoder, tilgange og perspektiver: En introduktion. I: Brinkmann, S. \& Tanggaard, L. (red.), Kvalitative metoder. En grundbog (2. udg., s.13-24). Hans Reitzels Forlag.

Buch, B., Brænder, B., Jensen, M.-A., Gents, S. D., \& Rasmussen, C. S.(2018). Når leg er for alvor. I: Møller, H. H., Andersen, I. H., Kristensen, K.,\& Rasmussen, , C. S. (red.), Leg i Skolen. Forlaget Unge Pædagoger.

Buch, B., Brænder, B., Jensen, M.-A., Gents, S. D., Rasmussen, C. S., \& Trolle, J. (2020). Funktionel tværfaglighed i en forestillet lokalkontekst - åben skole som scenariedidaktik. I: Knudsen, L. E. D., Jensen, L. L., Thomsen, A. V., \& Fredlund, M. (red.), Åben Skole (s.108-126). Syddansk Universitetsforlag.

Cowi (2018). Projektet 'Foreningslivet ind i folkeskolen'. Evaluering. Roskilde Kommune.

Danmarks Evalueringsinstitut. (2018a). Åben Skole - en kortlægning af skolernes samarbejde med omverdenen.

Danmarks Evalueringsinstitut. (2018b). Skolernes samarbejde med erhvervslivet.

DGI. (u.å.). Hvad er Den Åbne Skole?https://www.dgi.dk/samarbejd/om-vores-indsatser/ programomraader/dgi-skoler-institutioner/aaben-skole/for-foreningen

Hammershøj, L. G. (2020). Åben skole som formålsstyret pædagogik: Inspiration til dannelse og kreativitet. Knudsen, L. E.D., Jensen, L. L., Thomsen, A. V., \& Fredslund, M. (red.), Aben skole (s.75-90). Syddansk Universitetsforlag.

Hein, G. (2012). Progressive Museum Practice. John Dewey and Democracy. Routledge.

Holst, F. (2016). Musikalske fællesskaber i det tredje rum. Unge pædagoger, 3, 66-75.

Hooper-Greenhill, E. (2007). Museums and Education. Purpose, pedagogy, performance. Routledge.

Hyllested, T., \& Rasmussen, C. S. (2013). Skolen i virkeligheden. Forlaget Unge Pædagoger. Jacobsen, R. H., Bjørnholt, B., Krassel, K. F., Nørgaard, E., Jakobsen, S. T., Flarup, L. H., Munch, L., Møller-Haastrup, T., Nielsen, M. H., \& Nygaard, H. (2017). En længere og mere varieret skoledag. Implementerings- og effektundersøgelse. Rapport. VIVE. www.kora.dk 
Jensen, L. L. (2020). Dannelse til medborgerskab i den åbne skole: med skoleprojektet GEOkids i Odsherred som omdrejningspunkt. I: Knudsen, L. E. D., Jensen, L. L., Thomsen, A. V., \& Fredslund, M. (red.) Aben skole (s.161-180). Syddansk Universitetsforlag.

Johnsen, K., \& Andersen, M. D. (ansv.)(2019a). Museernes undervisningspraksis - En national kortlægning af statslige og statsanerkendte museers undervisningspraksis 2018. https://skoletjenestenetvaerk.dk/wp-content/uploads/2019/04/Museernes-undervisningspraksis. pdf

Johnsen, K., \& Andersen, M. D. (ansv.)(2019b). Skole-virksomhedssamarbejde med kommunal forankring - en undersøgelse af organiseringer og erfaringer. https://skoletjenestenetvaerk. dk/wp-content/uploads/2019/04/Skole-virksomhedssamarbejde-m-kommunal-forankring.pdf

Kock, B. (2017). Bevægelse og idræt i skolereformen. Unge Pædagoger, 1, 71-78.

Knudsen, G. L., \& Olesen, M. B. (2017). Museet $i$ den åbne skole. Læring fra partnerskabers udvikling af undervisningsforløb med anbefalinger til museer, skoler og kommuner. https://slks.dk/fileadmin/user_upload/0_SLKS/Dokumenter/Museer/Fakta_om_museerne/Videndeling/Museet_i_den_aabne_skole_foelgeforskningsrapport__A4_WEB. pdf

Knudsen, L. E. D. (2016). Åben skole - paradoks og pædagogik. Unge Pædagoger, 3, 3-12.

Knudsen, L.E.D. (2020a). Introduktion. Om baggrund, bredde og sammenhænge i åben skole. I: Knudsen, L. E. D., Jensen, L. L., Thomsen, A. V., \& Fredslund, M. (red.), Åben skole (s. 9-25). Syddansk Universitetsforlag.

Knudsen, L. E. D. (2020b). Den didaktiske kiasme: om modsætninger, der jager hinanden i åben skole. I: Knudsen, L. E. D., Jensen, L. L., Thomsen, A. V., \& Fredslund, M. (red.) Åben skole (s. 183-209). Syddansk Universitetsforlag.

Knudsen, L. E. D., Jensen, M. E., \& Shakoor, L. R. (2017). Vi vil gerne den der autencitet. Unge Pædagoger, 4, 47-57.

Lejre Kommune (u.å.). Grøn generation. https://www.lejre.dk/borger/børn-unge-og-familie/ skole/vores-skoler/groen-generation

Lynggaard, K. (2015). Dokumentanalyse. I: Brinkmann, S., \& Tanggaard, L. (red.), Kvalitative metoder. En grundbog (2. udg., s.153-168). Hans Reitzels Forlag.

Nationalpark Skjoldungernes land (u.å.). Bliv Skjolunge. https://nationalparkskjoldungernesland.dk/undervisning/bliv-skjoldunge/

Nielsen, C. P., Hansen, A. T., Jensen, V. M., \& Arendt, K. S. (2015). Folkeskolereformen. Beskrivelse af 2. dataindsamling blandt elever. Det Nationale Forskningscenter for Velfærd.

Rosenbäck I. S., \& Knudsen, L. E. D. (2020). Pædagogik og partnerskaber - et litteraturreview om samarbejder mellem skoler og lokalsamfund. I: Knudsen, L. E. D., Jensen, L. L., Thomsen, A.V., \& Fredslund, M. (red.), Åben skole (s. 250-265). Syddansk Universitetsforlag.

Schilhab, T. (2017). Læring og dannelse ude. Unge Pædagoger: Hvem Spiller Med i Åben Skole?, 4, 78-85.

Seligmann, T. (red.) (2014). Praksismanual. Samarbejde mellem museer, læreruddannelser, skoler. Museet for samtidskunst.

Shakoor, L. R., \& Haastrup, L. (2016). På vej mod partnerskaber i den åbne skole. Unge Pædagoger, 3, 94-102.

Tanggaard, L., \& Brinkmann, S. (2015). Interviewet: Samtalen som forskningsmetode. I: Brinkmann, S., \& Tanggaard, L. (red.), Kvalitative metoder. En grundbog (2. udg., s. 29-53). Hans Reitzels Forlag. 
Thorhauge, S. (2014). Interface learning. New goals for museum and upper secondary school collaboration. Ph.d.-afhandling. Aarhus Universitet.

Torhauge, S., \& Christensen, M. (2018). KULT-Projektet. Følgeforskningens resultater og anbefalinger. Rapport. HistorieLab.

Undervisningsministeriet (2018). Statusredegørelse for folkeskolens udvikling 2017/18. https:// backend.folkeskolen.dk/ /6/7/181220-statusredegoerelse-for-folkeskolens-udvikling-2017-2018.pdf

Vestergaard, A. (2016). Eksterne partnere i naturfagsundervisning: skole-virksomhedssamarbejde. Aarhus Universitet, DPU.

Villadsen, D. (2016). Åben skole og læringsmålstyret undervisning. Unge Pædagoger, 3, 50-60.

Østergaard, H., \& Gerlach, D. (2016). Æstetisk læring og kunstnerisk samskabelse som demokratisk dannelse. Unge Pædagoger, 3, 13-27. 